\title{
Domestic violence in rural currently married women: effects on utilization of reproductive and maternal health services
}

\author{
Rajiv Kumar Gupta ${ }^{1 *}$, Bhavna Langer ${ }^{1}$, Parveen Singh ${ }^{2}$, Rashmi Kumari', \\ Najma Akhter ${ }^{1}$, Riya Gupta ${ }^{3}$
}

\begin{abstract}
${ }^{1}$ Department of Community Medicine, Government Medical College, Jammu, Jammu and Kashmir, India
${ }^{2}$ Directorate of Health Services, Jammu, Jammu and Kashmir, India

${ }^{3}$ Department of Community Medicine, Acharya Shri Chander College of Medical Sciences and Hospital, Sidhra, Jammu, Jammu and Kashmir, India
\end{abstract}

Received: 27 November 2017

Accepted: 26 December 2017

\section{*Correspondence:}

Dr. Rajiv Kumar Gupta,

E-mail: rajivguptagmc@ rediffmail.com

Copyright: (c) the author(s), publisher and licensee Medip Academy. This is an open-access article distributed under the terms of the Creative Commons Attribution Non-Commercial License, which permits unrestricted non-commercial use, distribution, and reproduction in any medium, provided the original work is properly cited.

\section{ABSTRACT}

Background: Domestic violence remains a public health concern in India due to its high prevalence and adverse effects on pregnancy outcomes. Domestic violence in low and middle income countries has emerged as a priority among researchers and policy makers who are primarily concerned with women $\mathrm{s}$ health and empowerment. The study aimed to assess the relationship between domestic violence and women's use of reproductive and maternal health services.

Methods: The present study was conducted among currently married rural women in reproductive age group (15-49 Years). Four villages in Kot Balwal Block were selected randomly and all the currently married women who were willing to give informed verbal consent were administered the questionnaire. The questionnaire was pilot tested by the authors. Data was analysed using proportion sand chi square test was used as a test of significance.

Results: Prevalence of domestic violence was reported to be $49.12 \%$. Regarding empowerment, the results revealed that while $65.3 \%$ of the respondents were able to decide on their health, only $20.7 \%$ had say in household purchases. Attitude towards wife beating was strongly negative as $95.7 \%$ rejected wife beating. Levels of education, exposure to media, intake of alcohol by partners and spousal age difference were statistically significant $(\mathrm{p}<0.05)$ in relation to use of reproductive and maternal health services.

Conclusions: The study has revealed that women's empowerment has a positive impact on use of reproductive and maternal health services. Multi-sector collaboration in initiating programs and interventions to improve women's empowerment, increase educational attainment and reduction of gender based violence should be a priority for the health planners.

Keywords: Domestic violence, Reproductive and maternal health services, Women empowerment

\section{INTRODUCTION}

The issue of domestic violence against women in resource poor countries has emerged as a growing concern among policy makers concerned with women's health and empowerment. World Health Organisation
(WHO) has defined domestic violence as "the range of sexually, psychologically and physically coercive acts used against adult and adolescent women by current or former male intimate partners", illustrating that domestic violence includes more than physical violence. ${ }^{1}$ Estimates 
suggest that the life time prevalence of partner violence falling between $23 \%$ and $49 \%$. $^{2}$

Maternal, newborn and child mortality skill remain the major public health problems in India. Estimates show that 2,87,000 women die worldwide from complications of pregnancy and childbirth with $87 \%$ of these deaths occurring in sub Saharan Africa and South Asia. ${ }^{3}$

Access to modern contraceptive methods can avert 22$30 \%$ of maternal deaths while presence of skilled birth attendant during childbirth and emergency obstetric care can prevent up to $60 \%$ of maternal deaths and $40 \%$ of intrapartum related neonatal deaths. ${ }^{4,5}$ Besides, women's empowerment, autonomy and decision-making power in family affairs including spending money have shown to positively influence the use of contraception, antenatal care, skilled birth attendant and vaccination services. ${ }^{6-8}$

Previous studies on the association between domestic violence and use of reproductive and maternal services had varied results. Studies in India, Bangladesh and Nepal have shown that women who experienced either physical violence alone or both physical and sexual violence have lower odds of receiving antenatal care compared with other women. ${ }^{6,7,9}$ Kishore et al found no association between use of antenatal care and domestic violence. ${ }^{10}$

There have been quite a few studies on prevalence of domestic violence and influence of socio demographic characteristics on domestic violence in India but there was paucity of research on the association between domestic violence, women's empowerment and use of reproductive and maternal health services.

The present study explores the association of spouse violence, women's empowerment and various socio demographic characteristics related to health care seeking for family planning, antenatal care and delivery service in rural currently married females in Northern India. Authors hope that evidence so generated would help policy makers and providers increase women's utilization of reproductive and maternal health services by facilitating development of strategies to address the issues of domestic violence and women s empowerment.

\section{METHODS}

The present cross sectional study was conducted among the currently married women in the age group of 15-49 years in a rural area of Jammu district. Before the start of the study, due permission was sought from Institutional Ethical Committee of GMC Jammu.

The study was conducted in Kot Balwal block of Jammu district. This health block was divided into four zones viz East, West, North and South. Using simple random technique, one village was selected from each of these zones. Thus, four villages were selected randomly for the purpose of the current study. The study sample was the currently married females (15-49 years) who were administered the questionnaire. The questionnaire was developed by the authors and was pilot tested on a group of 20 rural women attending the OPD of a tertiary care hospital. After pilot testing, some modifications were incorporated before putting it finally to the use.

All the eligible women in the selected villages were enquired about the domestic violence. The term domestic violence in the context of current study meant if the respondent had ever experienced physical violence or sexual violence or both. Only those females who gave a positive history of domestic violence were further interviewed. At the onset of the interview, respondents were enquired about socio demographic characteristics like fertility, literacy, employment status, age at marriage, partners alcohol intake and age difference between the spouses.

Among the utilization of reproductive and maternal health services, the respondents were enquired about current use of modern contraceptive method, utilization of 4 or more antenatal care (ANC) visits and availability of skilled birth attend (SBA) during the most recent birth. The women who gave birth in the five years preceding the survey were enquired if they have received antenatal care for their most recent birth and the number of ANC visits. The respondents were further enquired about their participation in household decision making and attitude towards wife beating.

\section{Statistical analysis}

The data thus collected was tabulated and analysed. Frequency distribution and percentages of socio demographic and key outcome variables were examined. (Chi square test was used as test of significance and $\mathrm{p}$ value $<0.05$ were considered statistically significant.

\section{RESULTS}

During the course of the study, 570 rural currently married women were enquired about the history of domestic violence and of these, 280 women gave positive history of domestic violence. The prevalence of domestic violence was found to be $49.12 \%$ (280/570). So, these 280 currently married women with a positive history of domestic violence were administered the questionnaire.

Among the respondents, $43.57 \%$ were in 25-34 year age group while $35.35 \%$ were in $35-49$ year age group. More than two-third were educated upto secondary or higher levels and only about one-third of them were employed. About $91 \%$ of the respondents had exposure to media and had married at age $>18$ years. About half $(49.2 \%)$ of the respondents had 1-2 living children and $31 \%$ had partners who consumed alcohol. Regarding spousal age difference, men were older in $90 \%$ cases and $60.4 \%$ respondents had a living son (Table 1). 
Table 1: Distribution of currently married women interviewed for DV by selected socio-demographic characteristics $(n=280)$.

\begin{tabular}{|c|c|c|c|}
\hline \multicolumn{2}{|c|}{ Socio demographic variable } & \multirow{2}{*}{$\begin{array}{l}\text { Number } \\
59\end{array}$} & \multirow{2}{*}{$\begin{array}{l}\text { Percentage } \\
21.07\end{array}$} \\
\hline Age in & $18-24$ & & \\
\hline completed & $25-34$ & 122 & 43.57 \\
\hline years & $34-49$ & 99 & 35.35 \\
\hline \multirow[b]{3}{*}{$\begin{array}{l}\text { Education } \\
\text { level }\end{array}$} & Illiterate & 27 & 9.64 \\
\hline & Primary & 61 & 21.78 \\
\hline & $\begin{array}{l}\text { Secondary } \\
\text { or Higher }\end{array}$ & 192 & 68.57 \\
\hline \multirow{2}{*}{$\begin{array}{l}\text { Employment } \\
\text { status }\end{array}$} & Employed & 92 & 32.85 \\
\hline & Not employed & 188 & 67.14 \\
\hline \multirow{2}{*}{$\begin{array}{l}\text { Exposure to } \\
\text { media }\end{array}$} & Yes & 256 & 91.43 \\
\hline & No & 24 & 8.57 \\
\hline \multirow{3}{*}{$\begin{array}{l}\text { Number of } \\
\text { living } \\
\text { children }\end{array}$} & 0 & 12 & 4.28 \\
\hline & $1-2$ & 138 & 49.28 \\
\hline & $>3$ & 130 & 46.42 \\
\hline \multirow{2}{*}{$\begin{array}{l}\text { Age at } \\
\text { marriage }\end{array}$} & $<18$ years & 25 & 8.93 \\
\hline & $\geq 18$ years & 255 & 91.07 \\
\hline \multirow{2}{*}{$\begin{array}{l}\text { Partners } \\
\text { alcohol intake }\end{array}$} & Yes & 87 & 31.07 \\
\hline & No & 193 & 68.93 \\
\hline \multirow{3}{*}{$\begin{array}{l}\text { Spouse age } \\
\text { difference }\end{array}$} & None & 27 & 9.64 \\
\hline & Man older & 252 & 90.00 \\
\hline & Women older & 01 & 0.35 \\
\hline \multirow{2}{*}{$\begin{array}{l}\text { Has a living } \\
\text { son }\end{array}$} & Yes & 162 & 60.44 \\
\hline & No & 106 & 39.56 \\
\hline
\end{tabular}

Table 2: Distribution of CMW interviewed for DV by empowerment in family- decision making and usage of specific reproductive and maternal health services $(\mathbf{n}=\mathbf{2 8 0})$.

\begin{tabular}{|c|c|c|c|}
\hline Question & Response & Number & $\%$ \\
\hline \multirow{6}{*}{$\begin{array}{l}\text { Family Decision } \\
\text { Making } \\
\text { Decide on own health } \\
\text { Decide on household } \\
\text { purchases } \\
\text { Decide on visiting } \\
\text { relatives/friends }\end{array}$} & Yes & 183 & 65.36 \\
\hline & No & 97 & 34.64 \\
\hline & Yes & 58 & 20.71 \\
\hline & No & 222 & 79.29 \\
\hline & Yes & 129 & 46.07 \\
\hline & No & 151 & 53.93 \\
\hline \multirow{2}{*}{$\begin{array}{l}\text { Attitude towards wife } \\
\text { beating } \\
\text { Rejects wife beating }\end{array}$} & Yes & 268 & 95.71 \\
\hline & No & 12 & 4.29 \\
\hline \multirow{2}{*}{$\begin{array}{l}\text { Currently using a } \\
\text { modern contraceptive } \\
\text { method }\end{array}$} & Yes & 176 & 62.86 \\
\hline & No & 104 & 37.14 \\
\hline \multirow{2}{*}{$\begin{array}{l}\text { Has availed } 4 \text { or more } \\
\text { antenatal visits during } \\
\text { pregnancy }\end{array}$} & Yes & 232 & 82.86 \\
\hline & No & 48 & 17.14 \\
\hline \multirow{2}{*}{$\begin{array}{l}\text { Skilled birth attendant } \\
\text { present during } \\
\text { delivery }\end{array}$} & Yes & 256 & 91.43 \\
\hline & No & 24 & 8.57 \\
\hline \multirow{2}{*}{$\begin{array}{l}\text { Capable of taking a } \\
\text { sick child to hospital }\end{array}$} & Yes & 223 & 79.64 \\
\hline & No & 57 & 20.36 \\
\hline
\end{tabular}

The respondents were enquired about their empowerment in family as far as the decision making was concerned.
$65.3 \%$ respondents were deciding on their own health, $79.2 \%$ had a say in household purchases while only $46.07 \%$ could decide on visiting a friend/relative.

An overwhelming $95.7 \%$ were rejecting wife beating. Among the utilization of reproductive and maternal health services, $62.8 \%$ respondents were using a modern contraceptive method while $82.8 \%$ had availed 4 or more antenatal visits during pregnancy.

Further $91.4 \%$ had skilled birth attendant (SBA) present during delivery and about $80 \%$ were capable of taking their sick child to the hospital (Table 2).

Table 3 shows that women's use of reproductive and maternal health services varies by socio-demographic characteristics.

The indicators like use of modern contraceptive methods, four or more antenatal care visits and delivery assisted by a skilled birth attendant varied in relation of socio demographic variables. For example, women in the age group of 18-24 years were using a modern contraceptive less than women in the age group 25-34 years.

Similarly, women in the age group of 25-34 years were having the maximum proportion (84.4\%) of antenatal visits as well as presence of skilled birth attendant during child birth $(96.7 \%)$ in comparison to other age groups.

Among other socio-demographic variables, levels of education, exposure to media, intake of alcohol by partner and spousal age difference were all significantly associated with use of reproductive and maternal health services by the respondents $(\mathrm{p}<0.05)$.

Empowered women who had a say on their own health care or visiting family/relatives were having significantly higher usage of modern contraceptive methods $(p<0.05)$.

There was no association between women facing domestic violence and usage of reproductive and maternal health services (although the respondents who were rejecting wife beating were using all three of these services in higher proportion).

Also, those respondents who were capable of taking their sick child to a hospital were also using reproductive and maternal health services in higher proportion compared to the females who were unable to take their sick child to a hospital (Table 4).

\section{DISCUSSION}

The prevalence of domestic violence was found to be $49.12 \%$, which was consistent with the results of Hindin et al and Rahman et al in Kenya and Bangladesh respectively. ${ }^{6,11}$ A lower rate to the tune of $39 \%$ was reported by Msuya SE et al in Tanzania. ${ }^{12}$ 
Table 3: Relationship of women's use of reproductive and maternal health services by selected socio-demographic characteristics.

\begin{tabular}{|c|c|c|c|c|c|c|c|c|c|c|}
\hline \multirow[t]{2}{*}{ Variable } & \multirow[t]{2}{*}{ Total } & \multicolumn{2}{|c|}{$\begin{array}{l}\text { Current use of } \\
\text { modern contraceptive } \\
\text { method ( } n=176)\end{array}$} & \multirow[t]{2}{*}{$\begin{array}{l}\mathbf{P} \\
\text { value }\end{array}$} & \multicolumn{2}{|c|}{$\begin{array}{l}4 \text { or }>\text { ANC visits } \\
(n=232)\end{array}$} & \multirow[t]{2}{*}{$\begin{array}{l}\mathbf{P} \\
\text { value }\end{array}$} & \multicolumn{2}{|c|}{$\begin{array}{l}\text { Skilled birth attends } \\
\text { during delivery } \\
(\mathrm{n}=\mathbf{2 5 6})\end{array}$} & \multirow[t]{2}{*}{$\begin{array}{l}P \\
\text { value }\end{array}$} \\
\hline & & Yes $(\%)$ & No $(\%)$ & & Yes $(\%)$ & No $(\%)$ & & Yes $(\%)$ & No $(\%)$ & \\
\hline \multicolumn{11}{|c|}{ Age (years) } \\
\hline $18-24$ & 59 & $38(64.41)$ & 21(35.59) & \multirow{3}{*}{0.00} & $52(88.13)$ & $07(11.87)$ & \multirow{3}{*}{0.00} & $55(93.22)$ & $04(6.78)$ & \multirow{3}{*}{0.00} \\
\hline $25-34$ & 122 & $92(75.40)$ & $30(24.59)$ & & $103(84.42)$ & $19(15.57)$ & & $118(96.72)$ & $04(3.28)$ & \\
\hline $34-49$ & 99 & $46(46.46)$ & $53(53.54)$ & & $21(21.21)$ & $78(78.79)$ & & $83(83.83)$ & $16(16.16)$ & \\
\hline \multicolumn{11}{|c|}{ Education level } \\
\hline Illiterate & 27 & $9(33.33)$ & $18(66.67)$ & \multirow{3}{*}{0.00} & $20(74.07)$ & $07(25.93)$ & \multirow{3}{*}{0.00} & $21(77.78)$ & $06(22.22)$ & \multirow{3}{*}{0.01} \\
\hline Primary & 61 & $31(50.81)$ & $30(49.18)$ & & $42(68.85)$ & $19(31.15)$ & & $54(88.52)$ & $07(11.48)$ & \\
\hline $\begin{array}{l}\text { Secondary } \\
\text { or Higher }\end{array}$ & 192 & $136(70.83)$ & $56(29.17)$ & & $170(88.54)$ & $22(11.46)$ & & $181(94.27)$ & $11(5.73)$ & \\
\hline \multicolumn{11}{|c|}{ Employment status } \\
\hline Employed & 92 & $86(93.47)$ & $6(6.52)$ & \multirow[b]{2}{*}{0.00} & $80(86.96)$ & $12(13.04)$ & \multirow[b]{2}{*}{0.20} & $88(95.65)$ & $04(4.35)$ & \multirow[b]{2}{*}{0.07} \\
\hline $\begin{array}{l}\text { Not } \\
\text { employed }\end{array}$ & 188 & $90(47.87)$ & $98(52.13)$ & & $152(80.85)$ & $36(19.15)$ & & $168(89.36)$ & $20(10.64)$ & \\
\hline \multicolumn{11}{|c|}{ Exposure to media } \\
\hline Yes & 256 & $166(64.84)$ & $90(35.16)$ & \multirow{2}{*}{0.02} & $220(85.93)$ & $36(14.06)$ & \multirow{2}{*}{0.00} & $242(94.53)$ & $14(5.47)$ & \multirow{2}{*}{0.00} \\
\hline No & 24 & $10(41.67)$ & $14(58.33)$ & & $12(50.00)$ & $12(50.00)$ & & $14(58.33)$ & $10(41.67)$ & \\
\hline \multicolumn{11}{|c|}{ Number of living children } \\
\hline 0 & 12 & $04(33.33)$ & $8(66.67)$ & \multirow{3}{*}{0.06} & $08(66.66)$ & $04(33.33)$ & \multirow{3}{*}{0.10} & $06(50.00)$ & $06(50.00)$ & \\
\hline $1-2$ & 138 & $92(66.67)$ & $46(33.33)$ & & $120(86.95)$ & $18(13.04)$ & & $128(92.75)$ & $10(7.25)$ & 0.00 \\
\hline$>3$ & 130 & $80(61.53)$ & $50(38.46)$ & & $104(80.00)$ & $26(20.00)$ & & $122(93.84)$ & $08(6.15)$ & \\
\hline Age at mar & lage & & & & & & & & & \\
\hline$<18$ years & 25 & $16(64.00)$ & $9(36.00)$ & 000 & $15(60.00)$ & $10(40.00)$ & 000 & $16(64.00)$ & $09(36.00)$ & 000 \\
\hline$>18$ years & 255 & $160(62.74)$ & $95(37.25)$ & 0.90 & $217(85.09)$ & $38(14.90)$ & 0.00 & $240(94.11)$ & $15(5.88)$ & 0.00 \\
\hline Partners a & ohol in & & & & & & & & & \\
\hline Yes & 87 & $20(22.98)$ & $67(77.01)$ & & $52(59.77)$ & $35(40.23)$ & & $70(80.45)$ & $17(19.54)$ & \\
\hline No & 193 & $156(80.83)$ & $37(19.17)$ & 0.00 & $180(93.26)$ & 13(6.74) & 0.00 & $186(96.37)$ & $07(3.63)$ & 0.00 \\
\hline Spouse age & liffere & & & & & & & & & \\
\hline None & 27 & 26(96.29) & $01(3.70)$ & & $18(66.67)$ & $09(3.33)$ & & $20(74.07)$ & $07(25.93)$ & \\
\hline Man older & 252 & $150(59.52)$ & $102(40.48)$ & 000 & 214(84.92) & $38(15.08)$ & 0.00 & $235(93.25)$ & $17(6.75)$ & 0.00 \\
\hline $\begin{array}{l}\text { Women } \\
\text { older }\end{array}$ & 01 & $00(0.00)$ & 01(100.00) & 0.00 & $00(0.00)$ & 01(100.00) & 0.00 & 01(100.00) & $00(0.00)$ & 0.00 \\
\hline Has a livi & son & & & & & & & & & \\
\hline Yes & 162 & $85(52.46)$ & $77(47.53)$ & & $142(87.65)$ & $20(12.35)$ & & 157(96.91) & $05(3.09)$ & \\
\hline No & 106 & $91(85.84)$ & $15(14.15)$ & 0.00 & $90(84.90)$ & $16(15.09)$ & 0.51 & 99(93.39) & $07(6.60)$ & 9 \\
\hline
\end{tabular}

Table 4: Women's utilization of reproductive and maternal health services by their empowerment variables $(\mathrm{n}=\mathbf{2 8 0})$.

\begin{tabular}{|c|c|c|c|c|c|c|c|c|}
\hline \multirow[t]{2}{*}{ Variable } & & \multicolumn{2}{|c|}{$\begin{array}{l}\text { Current use of modern } \\
\text { contraceptive method } \\
(\mathrm{n}=176)\end{array}$} & & \multicolumn{2}{|l|}{$\begin{array}{l}4 \text { or }>\text { ANC } \\
\text { visits } \\
(n=232)\end{array}$} & \multicolumn{2}{|c|}{$\begin{array}{l}\text { Skilled birth } \\
\text { attends during } \\
\text { delivery ( } n=256 \text { ) }\end{array}$} \\
\hline & & Total & $\mathbf{N}$ & $P$ value & $\mathbf{N}$ & $P$ value & $\mathbf{N}$ & $P$ value \\
\hline \multirow{2}{*}{$\begin{array}{l}\text { Decision on own } \\
\text { health }\end{array}$} & Yes & 183 & $143(78.14)$ & \multirow{2}{*}{0.00} & $151(82.51)$ & \multirow{2}{*}{0.94} & $163(89.07)$ & \multirow{2}{*}{0.68} \\
\hline & No & 97 & $33(34.02)$ & & $81(83.50)$ & & $93(95.87)$ & \\
\hline \multirow{2}{*}{$\begin{array}{l}\text { Decision on } \\
\text { household purchases }\end{array}$} & Yes & 58 & $46(79.31)$ & \multirow{2}{*}{0.09} & $51(87.93)$ & \multirow{2}{*}{0.72} & $52(89.65)$ & \multirow{2}{*}{0.90} \\
\hline & No & 222 & $130(58.55)$ & & $181(81.53)$ & & 204(91.89) & \\
\hline \multirow{2}{*}{$\begin{array}{l}\text { Decision on visiting } \\
\text { relatives/ friends }\end{array}$} & Yes & 129 & 111(86.04) & \multirow{2}{*}{0.00} & $112(86.82)$ & \multirow{2}{*}{0.62} & $116(89.92)$ & \multirow{2}{*}{0.86} \\
\hline & No & 151 & $65(43.04)$ & & $120(79.47)$ & & $140(92.71)$ & \\
\hline \multirow{2}{*}{ Rejects wife beating } & Yes & 268 & $168(62.68)$ & \multirow{2}{*}{0.88} & $222(82.83)$ & \multirow{2}{*}{0.98} & 244(91.04) & \multirow{2}{*}{0.82} \\
\hline & No & 12 & $08(66.66)$ & & $10(83.33)$ & & $12(100.00)$ & \\
\hline \multirow{2}{*}{$\begin{array}{l}\text { Capable of taking a } \\
\text { sick child to hospital }\end{array}$} & Yes & 223 & $150(67.26)$ & \multirow{2}{*}{0.13} & $202(90.58)$ & \multirow{2}{*}{0.02} & $216(96.86)$ & \multirow{2}{*}{0.15} \\
\hline & No & 57 & $26(45.61)$ & & $30(52.6)$ & & $40(70.17)$ & \\
\hline
\end{tabular}


Despite a constant feature in the society, domestic violence was found not to be associated with any of the reproductive and maternal health service utilization indicators, current use of modern contraceptive methods, having four or more antenatal care visits during the most recent pregnancy and delivery assisted by a skilled birth attendant. These findings are in agreement with those reported by Msuya SE et al in Tanzania and Tuladhar et al from Nepal., ${ }^{72}$ Kishor and Johnson didn't find an association between domestic violence and antenatal care use in seven of the nine countries reviewed in their study, but they did observe that domestic violence influenced the use of antenatal care during the first trimester. ${ }^{10}$

Lack of consistent associations between domestic violence and use of antenatal care or institutional delivery has been reported by Hindin et al. ${ }^{11}$ In contrast Rahman et al reported from Bangladesh that women's experience of domestic violence was associated with $31 \%$ and $52 \%$ lower odds of utilising antenatal care during pregnancy and skilled birth attendant services during child birth respectively. ${ }^{6}$ Hindin et al found that Rwandan women who had experienced domestic violence had $29 \%$ lower odds of delivering in the health facilities. ${ }^{11}$ Meiksin R et al reported that overall women who experienced domestic violence were more likely than other rural women to have an unplanned pregnancy, fewer than four antenatal visits or a baby born smaller than average. ${ }^{13}$ On the other hand Alio AP et al reported that women who had experienced domestic violence were significantly more likely to report that they had used contraception compared to women who hadn't experienced domestic violence. ${ }^{14}$

Among the women's empowerment indicators decision on her own health and decision to visit friends/relatives was associated with current usage of modern contraceptive methods. These results are congruence with Wado et al who also reported that decision making autonomy was positively associated with ever use of contraceptives among married women in Ethiopia. ${ }^{8}$ Tuladhar et al from Nepal reported that highly empowered women were significantly more likely to have four or more antenatal visits during pregnancy compared to women with low/moderate empowerment. ${ }^{7}$ However Msuya SE et al Tanzania found that women's empowerment was associated with usage of modern contraceptive, having four or more antenatal visits as well as use of skilled birth attendant during child birth. ${ }^{12}$

Use of contraception is a sensitive matter in most of the rural patriarchal societies and women most of the time needs consent from spouse before adopting a contraceptive method. To use health facilities during delivery, women need cooperation from their husbands in matters pertaining to travel and financial help in case of emergencies and health facility costs. So, strengthening women's empowerment should be a priority using mechanisms both inside and outside the health sector.
The socio-demographic variables that influenced women's utilisation of reproductive and maternal health services in the current study were age in years, education levels, exposure to media, partner's alcohol intake and spousal age difference. Consistent with the findings of the present study, results from the other developing countries have shown that educated women living in wealthier households and who live in urban areas have better utilisation of reproductive and maternal health services compared to rural and less educated women. ${ }^{5,15,16}$ Need of the hour is for a multi-sectoral approach in addressing these factors to improve overall health and outcomes for women and their children.

The cross-sectional nature of the study doesn't allow the inference of causal relationships. A small sample size limited to a certain geographical area is another limitation. Domestic violence and utilization of reproductive and maternal health services rely on the respondents self-reporting and under reporting can occur.

\section{CONCLUSION}

The study has revealed that instead of domestic violence, it is women's empowerment which is related to the utilization of reproductive and maternal health services with empowered women having higher levels of service utilization. Utilization of services was affected by women's literacy, exposure to media, partners alcohol intake and spouse age difference. National Health Programs particularly related to mother and child welfare have contributed to better utilization of the services by the stake holders, even in rural areas, as the results of the current study have depicted.

Funding: No funding sources

Conflict of interest: None declared

Ethical approval: The study was approved by the Institutional Ethics Committee

\section{REFERENCES}

1. World Health Organization. Violence against women (FRH/WHD/96.27). Geneva, Switzerland: Author; 1996. Available

at http://apps.who.int/iris/bitstream/10665/63277/1/FR H_WHD_96.27.pdf. Accessed on 15 November 2017

2. Garcia-Moreno C, Jansen HA, Ellsberg M, Heise L, Watts $\mathrm{CH}$. Prevalence of intimate partner violence: findings from the WHO multi-country study on women's health and domestic violence. Lancet. 2006 Oct 13;368(9543):1260-9.

3. WHO, and UNICEF. 2013. Countdown to 2015 Report; Maternal, Newborn and Child Survival; Accountability for Maternal, Newborn and Child Survival. Available at http://www.countdown2015mnch.org/. Accessed on 15 November 2017

4. Bongaarts J, Cleland J, Townsent JW, Bertrand JT, Gupta MD. Family Planning Programs for the $21^{\text {st }}$ 
Century: Rationale and Design. New York, New York, USA: The Population Council;2012.

5. WHO, and UNICEF. 2012. Countdown to 2015 Report; Maternal, Newborn and Child Survival; Building a Future for Women and Children. Available https://reliefweb.int/sites/reliefweb.int/files/resources /Countdown\%2520complete\%25200606.pdf.

Accessed on 17 November 2017

6. Rahman M, Nakamura K, Seino K, Kizuki M. Intimate partner violence and use of reproductive health services among married women: evidence from a national Bangladeshi sample. BMC public health. 2012 Oct 29;12(1):913.

7. Tuladhar S, Khanal KR, Lila KC, Ghimire PK, Onta K. Women's Empowerment and Spousal Violence in Relation to Health Outcomes in Nepal: Further Analysis of the 2011 Nepal Demographic and Health Survey. Calverton, Maryland, USA: Nepal Ministry of Health and Population, New ERA, and ICF International;2013.

8. Wado YD. Women's Autonomy and Reproductive Healthcare Seeking Behavior in Ethiopia. DHS Working Papers No. 91. Calverton, Maryland, USA: Macro International;2013.

9. Ahmed S, Koenig MA, Stephenson R. Effects of domestic violence on perinatal and early-childhood mortality: evidence from north India. Am J Public Health. 2006 Aug;96(8):1423-8.

10. Kishor S, Johnson K. Profiling domestic violence: a multi-country study. Calverton, Maryland, USA: ORC Macro;2004.

11. Hindin JM, Kishor S, Ansara DL. Intimate partner violence among couples in 10DHS Countries: Predictors and Health Outcomes. DHS Analytical
Studies No 18. Calverton, Maryland, USA: Macro International;2008.

12. Msuya SE, Adinan J, Mosha N. intimate partner violence and empowerment among women in Tanzania: prevalence and effect on utilization of reproductive and maternal health services. DHS Working Papers, USAID;2014.

13. Meiksin R, Meekers D, Thompson S, Hagopian A, Mercer MA. Domestic violence, marital control, and family planning, maternal, and birth outcomes in Timor-Leste. Maternal Child Health J. 2015 Jun 1;19(6):1338-47.

14. Alio AP, Nana PN, Salihu HM. Spousal violence and potentially preventable single and recurrent spontaneous fetal loss in an African setting: crosssectional study. Lancet. 2009;373(9660):318-24.

15. Mpembeni RN, Killewo JZ, Leshabari MT, Massawe SN, Jahn A, Mushi D et al. Use pattern of maternal health services and determinants of skilled care during delivery in Southern Tanzania: implications for achievement of MDG-5 targets. BMC pregnancy and childbirth. 2007 Dec 6;7(1):29.

16. National Bureau of Statistics (NBS) [Tanzania], and ICF Macro. 2011. Tanzania Demographic and Health Survey 2010. Dar es Salaam, Tanzania: National Bureau of Statistics, and ORC Macro. Available at https://dhsprogram.com/pubs/pdf/FR243/FR243[24J une2011].pdf

Cite this article as: Gupta RK, Langer B, Singh P, Kumari R, Akhter N, Gupta R. Domestic violence in rural currently married women: effects on utilization of reproductive and maternal health services. Int $\mathbf{J}$ Reprod Contracept Obstet Gynecol 2018;7:602-7. 